\title{
Ecodrainage Model to Handle the Inundations in the City Center of Demak
}

\author{
Risa Niken R.T.H. ${ }^{1}$, S. Imam Wahyudi ${ }^{1}$, and Hermin Poedjiastoeti ${ }^{1}$ \\ ${ }^{1}$ Dept. of Civil Engineering, Universitas Islam Sultan Agung, Semarang, Indonesia \\ *Corresponding author: kheen.ndut@gmail.com
}

(Received: September $12^{\text {th }}, 2019$; Revised: October $25^{\text {th }}, 2019$ Accepted: October $30^{\text {th }}, 2019$ )

\begin{abstract}
The growth and development of the city is strongly influenced by an increase in population in line with the increasing demand for space and land. On the other hand, the availability of urban land is very limited, resulting in the conversion of land use to meet those needs. The development of the constructed land will ultimately increase surface runoff and decrease water that seeps into the ground, causing inundation or flooding and the threat of drought in urban areas. Therefore it is necessary to change the paradigm of the concept of a conventional drainage system to the concept of an environmentally friendly drainage system (ecodrainage). The ecodrainage concept is expected to be an effort to deal with inundation and groundwater conservation in city center of Demak. The quantity of the rainwater infiltration wells (RIW) was obtained based on the analysis to reduce the inundation in the city center of Demak. With the reference to the rainfall repetition period (RRP) of 2 years, 21 units of the well were needed to accommodate the rainwater runoff discharges of $0.878 \mathrm{~m}^{3} / \mathrm{s}$. Due to the land limits at the area of research, only could 20 units of the well be constructed, as a result, it could only reduce the inundation by $0.811 \mathrm{~m}^{3} / \mathrm{s}$ or $90.48 \%$. Considering the rainfall repetition period (RRP) of 5 years, around 40 units of rainwater infiltration wells (RIW) were needed to accommodate the rainwater runoff discharge of $1.70 \mathrm{~m}^{3} / \mathrm{s}$, yet only could 35 out of 40 wells as required be constructed, consequently, it was only able to reduce the inundation of $1.494 \mathrm{~m}^{3} / \mathrm{s}$ or $87.50 \%$. While based on the rainfall repetition period (RRP) of 10 years, around 61 units of the rainwater infiltration wells were needed to catch the rainwater runoff discharge of $2.554 \mathrm{~m}^{3} / \mathrm{s}$, but only could 47 units of the well out of 61 be constructed, so it was only able to reduce the inundation of $2.01 \mathrm{~m}^{3} / \mathrm{s}$ or $77.05 \%$ from the total inundation.
\end{abstract}

Keywords: ecodrainage; inundation; rainwater infiltration well

\section{Introduction}

The growth and development of the city is strongly influenced by an increase in population. The rapid increase of urban population has an impact on the increasing space and land requirements. On the other hand, the availability of urban land is very limited, resulting in the conversion of land use to meet those needs. Land development is built from the process of land conversion, which in turn will increase surface runoff which is one of the causes of inundation or flooding in urban areas. One of the factors causing inundation is the poor functioning of urban drainage. Drainage channels in urban areas not only drain rainwater, but also domestic or non-domestic waste water. The concept of drainage, which is generally applied in most areas today is the concept of conventional drainage. This concept has the principle that all rainwater and waste water are immediately flowed into the drainage channel to immediately reach the estuary. With the condition of drainage channels which can still optimally function, inundation will likely not occur, but it is unfortunate that most urban drainage systems do not function optimally. Therefore it is necessary to change the concept of drainage which can not only minimize the short-term drainage 
problem but also can deal with the problem of drainage in an integrated manner by implementing an environmentally drainage system (ecodrainage). Ecodrainage can be interpreted as an effort to drain and absorb some of the rainwater that flows through a channel in an area with the principle of water conservation. The city center of Demak is one of the areas experiencing problems as mentioned above. Therefore, it is necessary to study the Ecodrainage Model to handle the inundations in the area, and to formulate an ecodrainage technology as an effort to manage the issue and this can be achieved through making several targets, namely to evaluate the performance of the drainage network system in the city center of Demak; to formulate the existing water discharge and the plan for drainage channel in the area; to formulate the ecodrainage technology, as an effort to deal with the inundation; and to formulate quantity of ecodrainage technology, as an effort to deal with the issue of inundation in the city center. Therefore, the city center of Demak becomes clean, healthy and comfortable as well as free from inundations.

\section{Research Method}

\subsection{Research site}

This research was conducted in the village of Bintoro, the District of Demak, the Regency of Demak. See the following figure.

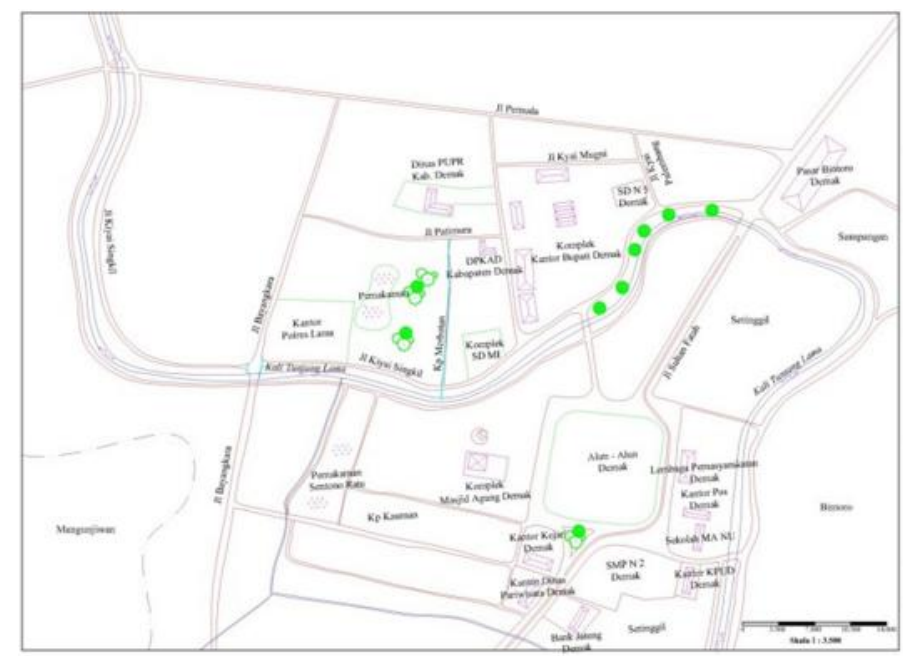

Fig. 1. Site Map of Research

\subsection{Research Approach}

The approach used in this research was descriptive research with quantitative models. In this study, the method was used to describe the phenomenon of inundation that occured in the city center of Demak when it rained. Therefore, a quantitative approach was needed to determine the ecodrainage model and its quantity in term of handling the inundation in the region.

\subsection{Data Collection}

The data used in this study were primary and secondary data. Primary data included data from the existing field survey results, regarding the condition of the drainage system in city center of Demak, while secondary data included data on the condition of existing drainage channels, rainfall, land use, land type maps, topographic maps, drainage network maps, and regulations concerning on urban drainage, as well as population data. 


\section{Results And Discussion}

\subsection{Analysis of the existing irrigation network performance}

The drainage model in the city center of Demak was conventional where it was noted not to function optimally and mostly caused inundation during the rainy season. The issues in the drainage were reported due to siltation as the result in sedimentation, clogging garbage, overgrowing wild plants and physical damages to buildings. Following was the profile of drainage performance in city center of Demak:

1. Drainage system on J1. Kyai Palembang was reported to function optimally. During the rainy season this drainage can accommodate maximum rainwater and dirty water discharges, that flow. Therefore, it did not cause runoff, which resulted in inundation around the area, especially during the rainy season;

2. Drainage Systems on Jl Pemuda, Jl. Bhayangkara and Jl. Kyai Singkil still functioned quite optimally. This was indicated by only a few inundation spots on the roadside that were less than 1 ha, with a inundation height of less than $0.10 \mathrm{~m}$ for $\pm 1-2$ hours with frequent frequency. Nevertheless, the inundation did not disturb the activities of the surrounding community;

3. Drainage system on Jl. Kyai Jebat and Jl. Kyai Mugni was reported not to function optimally. During the rainy season, this drainage was unable to accommodate the flowing water discharge and caused an inundation, which disrupted the surrounding. The inundation height was between 0.20 to $0.30 \mathrm{~m}$ with the area of inundation less than 1 ha and lasted for 4 to 8 hours;

4. Drainage systems in front of Pendopo also experienced runoff with the height of inundation around 0.10 to $0.20 \mathrm{~m}$ for an area of less than 1 ha and lasted for 2 to 4 hours;

5. Drainage systems in Merbotan and Jl. Pattimura was a kind of drainage with runoff. This runoff was reported to cause inundation, which entered the settlement and made the road closed to the public. The height of inundation was more than $0.50 \mathrm{~m}$ with an area of inundation between 1 to 2 ha and it lasted for more than 8 hours. This condition was concerned to disturb the surroundings.

\subsection{Hydraulics analysis}

\section{The existing discharge analysis}

This analysis was formulated to determine the storage capacity of the existing drainage channel in city center of Demak. The analytic calculation of the hydraulic was conducted using the following equation.

$$
Q=V \cdot A
$$

Explanation:

Q : Existing discharge ( $\left.\mathrm{m}^{3} / \mathrm{second}\right)$

$\mathrm{V}$ : Flow speed $(\mathrm{m} / \mathrm{second})$

A : Wet cross-sectional width $\left(\mathrm{m}^{2}\right)$

$$
A=B \times h
$$

Explanation:

A : Wet cross-sectional width $\left(\mathrm{m}^{2}\right)$

B : Width of the channel base (m)

h : Depth of water (m)

$$
p=b+2 h
$$

Explanation:

$\mathrm{p}$ : Wet cross-sectional circumpherence $(\mathrm{m})$

b : Width of channel base $(\mathrm{m})$

$\mathrm{h}$ : Depth of water (m) 
The calculation results can be seen in Table 1 as follow.

Table 1. The Analytical Calculation of the Existing Discharge of Drainage in the city center of Demak

\begin{tabular}{lcccccccccccc}
\hline \multicolumn{1}{c}{ Drainage Channel } & $\mathbf{L}(\mathbf{m})$ & $\begin{array}{c}\mathbf{b} \\
(\mathbf{m})\end{array}$ & $\mathbf{S}$ & $\begin{array}{c}\mathbf{h} \\
(\mathbf{m})\end{array}$ & $\begin{array}{c}\mathbf{A} \\
\left(\mathbf{m}^{2}\right)\end{array}$ & & $\begin{array}{c}\mathbf{P} \\
(\mathbf{m})\end{array}$ & $\begin{array}{c}\mathbf{R} \\
(\mathbf{m})\end{array}$ & $\begin{array}{c}\mathbf{V} \\
(\mathbf{m} / \mathbf{s})\end{array}$ & $\begin{array}{c}\mathbf{Q} \text { existing } \\
(\mathbf{m} / \mathbf{s})\end{array}$ \\
\hline $\begin{array}{l}\text { Secondary Drainage at Jl. Pemuda } \\
\text { Secondary Drainage at Jl. }\end{array}$ & 1.508 & 0,60 & 0,005 & 0,95 & 0,57 & 0,015 & 2,50 & 0,23 & 1,76 & 1,003 \\
Bhayangkara & 844 & 0,70 & 0,005 & 0,70 & 0,49 & 0,015 & 2,10 & 0,23 & 1,78 & 0,872 \\
Secondary Drainage at Jl. Kyai Jebat & 1.037 & 0,60 & 0,005 & 0,58 & 0,35 & 0,015 & 1,75 & 0,20 & 1,56 & 0,538 \\
Secondary Drainage in Merbotan & 192 & 0,60 & 0,005 & 0,40 & 0,24 & 0,015 & 1,40 & 0,17 & 1,45 & 0,349 \\
Tertiary Drainage at Jl. Pattimura & 560 & 0,30 & 0,005 & 0,30 & 0,09 & 0,015 & 0,90 & 0,10 & 1,02 & 0,091 \\
Secondary Drainage at Jl. Kyai & 314 & 0,60 & 0,005 & 0,50 & 0,30 & 0,015 & 1,60 & 0,19 & 1,54 & 0,463 \\
Palembang & 310 & 0,30 & 0,005 & 0,20 & 0,06 & 0,015 & 0,70 & 0,09 & 0,92 & 0,055 \\
Tertiary Drainage at Jl. Kyai Mugni & 574 & 0,70 & 0,005 & 0,80 & 0,56 & 0,015 & 2,30 & 0,24 & 1,84 & 1,029 \\
Drainage at Jl. Kyai Singkil & 202 & 0,60 & 0,005 & 0,40 & 0,24 & 0,015 & 1,40 & 0,17 & 1,45 & 0,349 \\
Drainage in front of Pendopo & & & & & & & & &
\end{tabular}

Explanation:

L : Length of Channel S: Channel Slope A: Wet cross-sectional area $\quad$ P : Wet cross-sectional circumference

$\mathrm{v}$ : Flow speed

b : Width of Channel $h$ : Depth of Water

Q : Existing Discharge

$\mathrm{n}$ : Manning Coeficient $\quad \mathrm{R}$ : Hydraulic radius

Drainage cannal could function optimally if the channel was able to accommodate the maximum rain discharge and did not cause inundation or flooding.

\section{Waste Discharge Analysis}

The research area belonged an urban area, so the discharges might consist of domestic and non-domestic discharge.

1. Domestic waste discharge

This domestic waste discharge was calculated through population projections for the next 10 years. These projections were calculated based on 3 methods, namely geometry, arithmetic and least square. Result in the calculation of the population growth projection for the next 10 years was obtained from the use of the Arithmetic calculation Method. Discharge calculated was the one that occurred during peak hours with a multiplier factor of 1.75 from the total water demand based on the following equation.

$$
Q d=100 \text { liter/person/day x 70\% x } \sum \text { Population density } \times A
$$

Explanation:

A : Width of area $\left(\mathrm{km}^{2}\right)$

From the calculation of domestic discharge, in 2019 and 2020, the amount of $0.028 \mathrm{~m}^{3} / \mathrm{s}$ was obtained, in 2021 to 2026 , the amount was $0.029 \mathrm{~m}^{3} / \mathrm{s}$, while in 2027 to 2028 , the number gained would be $0.030 \mathrm{~m}^{3} / \mathrm{s}$.

2. Nondomestic waste discharge

Non-domestic waste discharge from the research area originated from the offices and schools located in the regent office area of Demak on Jl. Kyai Jebat. The calculation of Non-domestic waste discharge which consisted of offices and schools was assumed to be the same for the next 10 years, which was equal to $0.00024\left(\mathrm{~m}^{3} / \mathrm{s}\right)$. The office was located in the regent office area of Demak on Jl. Kyai Jebat. Therefore, the calculation of non- 
domestic waste discharge became an input in the calculation of flood discharge in the drainage channel at Jl. Kyai Jebat.

\subsection{Hydrological Analysis}

\section{Analysis of Maximum Daily Rainfall Average}

Rainfall data were needed to calculate the maximum average of rainfall in the city center of Demak. Measuring stations used in this research were Palemraji Station (Sta No. 10111), Jatirogo Station (Sta No. 10113A) and Karangsari Station (Sta No. 10117) with the observation time of 15 years.

The calculation of the maximum daily-based rainfall average was conducted using the selected calculation method, namely Arithmetic. See table 2 to find out the calculation result in the maximum daily-based rainfall average.

Table 2. The average of maximum daily rainfall

\begin{tabular}{crrrrr}
\hline \multirow{2}{*}{ No. } & Year & \multicolumn{2}{c}{ Maximum daily rainfall (mm) } & Rainfall average \\
\cline { 3 - 5 } & & Palemraji & Jatirogo & Karangsari & 198.33 \\
\hline 1. & 2004 & 165 & 140 & 290 & 78.67 \\
2. & 2005 & 74 & 84 & 78 & 123.33 \\
3. & 2006 & 114 & 170 & 86 & 130.00 \\
4. & 2007 & 144 & 103 & 143 & 89.33 \\
5. & 2008 & 89 & 89 & 90 & 59.00 \\
6. & 2009 & 75 & 77 & 25 & 85.00 \\
7. & 2010 & 93 & 87 & 75 & 98.67 \\
8. & 2011 & 107 & 79 & 110 & 63.33 \\
9. & 2012 & 77 & 22 & 91 & 97.67 \\
10. & 2013 & 71 & 98 & 124 & 106.00 \\
11. & 2014 & 78 & 117 & 123 & 120.67 \\
12. & 2015 & 132 & 142 & 88 & 77.67 \\
13. & 2016 & 51 & 114 & 68 & 104.00 \\
14. & 2017 & 107 & 127 & 78 & 93.67 \\
15. & 2018 & 78 & 125 & 78 & $\mathbf{1 , 5 2 5 . 3 3}$ \\
\hline
\end{tabular}

Source : DINPUTARU, the Regency of Demak and the Analysis result of the author, 2019

Data on the average of maximum daily rainfall had been later obtained in the homogeneity test aimed to test whether the maximum rainfall occurred homogeneously in the entire research area. From the calculation, the point of homogeneity $(\mathrm{n}$; TR) which was $(15 ; 3.48)$ was obtained. Supposed that it was plotted on the homogeneity graph, it showed that the rainfall data used was homogeneous.

\section{Rainfall frequency analysis}

Based on the calculation result in the maximum daily rainfall average, the calculations of coefficient of variation $(\mathrm{Cv})$, coefficient of skewness $(\mathrm{Cs})$ and coefficient of kurtois $(\mathrm{Ck})$ were conducted to determine the calculation method of frequency distribution. Gumbel distribution method was selected as the method for rainfall frequency distribution. See table 3 for details. 
Risa Niken R.T.H., S. Imam Wahyudi, and Hermin Poedjiastoeti

Table 3. Calculation of the maximum daily rainfall using Gumbel Method

\begin{tabular}{cccccccc}
\hline T (year) & $\mathbf{x}$ & Sd & Sn & Yt & Yn & K & Xt \\
\hline $\mathbf{2}$ & 101.69 & 32.57 & 1.0206 & 0.3668 & 0.5128 & $(0.14)$ & 97.03 \\
$\mathbf{5}$ & 101.69 & 32.57 & 1.0206 & 1.5004 & 0.5128 & 0.97 & 133.21 \\
$\mathbf{1 0}$ & 101.69 & 32.57 & 1.0206 & 2.2510 & 0.5128 & 1.70 & 157.17 \\
$\mathbf{2 0}$ & 101.69 & 32.57 & 1.0206 & 2.9709 & 0.5128 & 2.41 & 180.14 \\
$\mathbf{2 5}$ & 101.69 & 32.57 & 1.0206 & 3.1993 & 0.5128 & 2.63 & 187.43 \\
$\mathbf{5 0}$ & 101.69 & 32.57 & 1.0206 & 3.9028 & 0.5128 & 3.32 & 209.88 \\
\hline
\end{tabular}

Source : Researcher analysis, 2019

Furthermore, the distribution suitability test was performed using the chi-square test and the Smirnov-Kolmogrov test. Based on the calculation results, it was known that the calculated value of chi square $\mathrm{X}^{2}$ was smaller than the value of chi square in the table. This could be interpreted that the distribution of selected rainfall Gumbel could be accepted and could be used as input in further analysis. According to the Smirnov-Kolmogorov test, it was found that the critical value of Smirnov-Kolmogrov was known that the Dmax value was 0.13. The Dmax value was smaller than the D value in the Smirnov-Kolmogrov table so that it could be interpreted that the distribution of selected rainfall was accepted as the basis for making calculations in subsequent analysis.

\section{Rainfall Intensity Analysis}

Rainfall intensity distribution could be calculated using several methods, namely the bell method, the Van Breen method and the Hasper method. Based on the calculation, the Van Breen was the method chosen in the calculation of the rainfall intensity curve formula. Furthermore, the calculation of rainfall intensity was done using the Talbot, Sherman and Ishiguro formula. Based on the equation calculation of the Talbot formula, used to calculate the intensity of the plan rainfall, the results of the calculations can be seen in Table 4. below.

Table. 4. Calculation of the plan rainfall intensity

\begin{tabular}{lcccc}
\hline \multicolumn{1}{c}{ Drainage Channels } & $\begin{array}{c}\text { tc } \\
\text { (Minutes) }\end{array}$ & $\begin{array}{c}\text { RRP of } 2 \\
\text { Years }\end{array}$ & $\begin{array}{c}\text { RRP of 5 } \\
\text { Years }\end{array}$ & $\begin{array}{c}\text { RRP of 10 } \\
\text { Years }\end{array}$ \\
\hline Secondary Drainage at Jl. Pemuda & 57.38 & 64.27 & 83.11 & 98.05 \\
Secondary Drainage at Jl. Bhayangkara & 34.77 & 82.36 & 104.41 & 121.97 \\
Secondary Drainage at Jl. Kyai Jebat & 41.92 & 74.74 & 95.54 & 112.06 \\
Secondary Drainage in Merbotan & 20.95 & 119.99 & 146.13 & 167.48 \\
Tertiary Drainage at Jl. Pattimura & 22.91 & 89.36 & 112.43 & 130.85 \\
Secondary Drainage at Jl. Kyai Palembang & 15.69 & 109.28 & 134.59 & 155.07 \\
Tertiary Drainage at Jl. Kyai Mugni & 16.62 & 105.39 & 130.34 & 150.46 \\
Drainage at Jl. Kyai Singkil & 22.90 & 93.98 & 117.65 & 136.6 \\
Drainage in front of Pendopo & 11.25 & 118.96 & 145.03 & 166.30 \\
\hline \hline
\end{tabular}

Source : Researcher analysis, 2019 


\section{Plan discharge analysis}

Since the research area belonged to an urban area, the plan discharge was a combination of rainwater discharge and waste discharge which could be calculated through the following equation:

$$
\mathrm{Q}=0,00278 \times \mathrm{C} \times \mathrm{I} \times \mathrm{A}
$$

Explanation :

Q : Peak Discharge ( $\left.\mathrm{m}^{3} / \mathrm{second}\right)$

C : Average of drainage coefficient

I : Rain intensity (mm/hour)

A : Width of water infiltration area (ha)

The calculations can be seen more clearly in the following table.

Table. 5. Plan discharge calculation with rain repetition period (RRP) of 2 years

\begin{tabular}{lcccccc}
\hline \multicolumn{1}{c}{ Drainage Channels } & $\mathbf{C}$ & $\mathbf{I}(\mathbf{m m} / \mathbf{h o u r})$ & $\mathbf{A}\left(\mathbf{k m}^{\mathbf{2}}\right)$ & $\begin{array}{c}\mathbf{Q}_{\text {rainfall }} \\
\left(\mathbf{m}^{\mathbf{3} / \mathbf{s}}\right)\end{array}$ & $\begin{array}{c}\mathbf{Q}_{\text {waste }} \\
\left(\mathbf{m}^{3} / \mathbf{s}\right)\end{array}$ & $\begin{array}{c}\mathbf{Q}_{\text {plan }} \\
\left(\mathbf{m}^{\mathbf{3} / \mathbf{s})}\right.\end{array}$ \\
\hline Secondary drainage at Jl. Pemuda & 0.59 & 6427 & 0.085 & 0.896 & 0.0032 & 0.899 \\
Secondary drainage at Jl. Bhayangkara & 0.59 & 82.36 & 0.047 & 0.635 & 0.0032 & 0.638 \\
Secondary drainage at Jl. Kyai Jebat & 0.59 & 74.74 & 0.055 & 0.670 & 0.0032 & 0.674 \\
Secondary drainage in Merbotan & 0.59 & 119.99 & 0.022 & 0.435 & 0.0032 & 0.438 \\
Tertiary Drainage at Jl. Pattimura & 0.59 & 89.36 & 0.040 & 0.586 & 0.0032 & 0.589 \\
Secondary drainage at Jl. Kyai Palembang & 0.59 & 109.28 & 0.012 & 0.222 & 0.0032 & 0.225 \\
Tertiary drainage at Jl. Kyai Mugni & 0.59 & 105.39 & 0,012 & 0.207 & 0.0032 & 0.211 \\
Drainage at Jl. Kyai Singkil & 0.59 & 93.98 & 0.062 & 0.961 & 0.0032 & 0.965 \\
Drainage in front of Pendopo & 0.59 & 118.96 & 0.006 & 0.125 & 0.0032 & 0.128 \\
\hline \hline
\end{tabular}

Source : Researcher analysis, 2019

Table. 6. Plan discharge calculation with rain repetition period (RRP) of 5 years

\begin{tabular}{lcccccc}
\hline \multicolumn{1}{c}{ Drainage channels } & $\mathbf{C}$ & $\begin{array}{c}\mathbf{I} \\
(\mathbf{m m} / \mathbf{h o u r})\end{array}$ & $\mathbf{A}\left(\mathbf{k m}^{\mathbf{2}}\right)$ & $\begin{array}{c}\mathbf{Q}_{\text {rainfall }} \\
(\mathbf{m} / \mathbf{s})\end{array}$ & $\begin{array}{c}\mathbf{Q}_{\text {waste }} \\
\left(\mathbf{m}^{3} / \mathbf{s}\right)\end{array}$ & $\begin{array}{c}\mathbf{Q}_{\text {plan }} \\
\left(\mathbf{m}^{\mathbf{3}} / \mathbf{s}\right)\end{array}$ \\
\hline Secondary drainage at J1. Pemuda & 0.59 & 83.11 & 0.085 & 1.158 & 0.0032 & 1.161 \\
Secondary drainage at Jl. Bhayangkara & 0.59 & 104.41 & 0.047 & 0.804 & 0.0032 & 0.808 \\
Secondary drainage at J1. Kyai Jebat & 0.59 & 95.54 & 0.055 & 0.857 & 0.0032 & 0.860 \\
Secondary drainage in Merbotan & 0.59 & 146.13 & 0.022 & 0.529 & 0.0032 & 0.533 \\
Tertiary drainage at Jl. Pattimura & 0.59 & 112.43 & 0.040 & 0.737 & 0.0032 & 0.740 \\
Secondary drainage at J1. Kyai Palembang & 0.59 & 134.59 & 0.012 & 0.274 & 0.0032 & 0.277 \\
Tertiary drainage at J1. Kyai Mugni & 0.59 & 130.34 & 0.012 & 0.256 & 0.0032 & 0.260 \\
Drainage at Jl. Kyai Singkil & 0.59 & 117.65 & 0.068 & 1.203 & 0.0032 & 1.207 \\
Drainage in front of Pendopo & 0.59 & 145.03 & 0.006 & 0.152 & 0.0032 & 0.155 \\
\hline
\end{tabular}

Source : Researcher analysis, 2019 
Risa Niken R.T.H., S. Imam Wahyudi, and Hermin Poedjiastoeti

Table 7. Plan discharge calculation with rainfall repetition period (RRP) of 10 years

\begin{tabular}{|c|c|c|c|c|c|c|}
\hline Drainage channels & $\mathbf{C}$ & I (mm/hour) & $\underset{\left(\mathbf{k m}^{2}\right)}{\mathbf{A}}$ & $\begin{array}{l}\text { Q } \\
\left(\mathbf{m}^{3} / \mathbf{s}\right)\end{array}$ & $\begin{array}{l}\mathbf{Q}_{\text {waste }} \\
\left(\mathbf{m}^{3} / \mathbf{s}\right)\end{array}$ & $\begin{array}{r}\mathbf{Q}_{\text {plan }} \\
\left(\mathbf{m}^{3} / \mathbf{s}\right)\end{array}$ \\
\hline Secondary drainage at Jl. Pemuda & 0.59 & 98.05 & 0.085 & 1.366 & 0.0032 & 1.369 \\
\hline Secondary drainage at Jl. Bhayangkara & 0.59 & 121.97 & 0.047 & 0.940 & 0.0032 & 0.943 \\
\hline Secondary drainage at Jl. Kyai Jebat & 0.59 & 112.06 & 0.055 & 1.005 & 0.0032 & 1.008 \\
\hline Secondary drainage in Merbotan & 0.59 & 167.48 & 0.022 & 0.607 & 0.0032 & 0.610 \\
\hline Tertiary drainage at Jl. Pattimura & 0.59 & 130.85 & 0.040 & 0.858 & 0.0032 & 0.861 \\
\hline $\begin{array}{l}\text { Secondary drainage at Jl. Kyai } \\
\text { Palembang }\end{array}$ & 0.59 & 155.07 & 0.012 & 0.315 & 0.0032 & 0.318 \\
\hline Tertiary drainage at Jl. Kyai Mugni & 0.59 & 150.46 & 0.012 & 0.296 & 0.0032 & 0.299 \\
\hline Drainage at Jl. Kyai Singkil & 0.59 & 136.6 & 0.068 & 1.397 & 0.0032 & 1.400 \\
\hline Drainage in front of Pendopo & 0.59 & 166.30 & 0.006 & 0.174 & 0.0032 & 0.178 \\
\hline
\end{tabular}

Source : Researcher analysis, 2019

\section{Inundation discharge analysis}

The calculation of inundation discharge was obtained from the difference between the plan discharge and the existing discharge. If the plan discharge is greater than the existing discharge, there would be an overflow in the channel, and vice versa if the plan discharge was smaller than the existing discharge, then the overflow would not occur because the channel was able to accommodate the water discharge flowed. The calculations can be seen in the following table.

Table 8. Inundation discharge calculation with rainfall repetition period (RRP) of 2 years

\begin{tabular}{|c|c|c|c|c|}
\hline Saluran Drainase & $\begin{array}{c}\text { Qrencana } \\
\left(\mathbf{m}^{3} / \mathbf{s}\right)\end{array}$ & $\begin{array}{c}\text { Qeksisting } \\
\left(\mathrm{m}^{3} / \mathbf{s}\right)\end{array}$ & $\begin{array}{c}\text { Q Qenangan } \\
\left(\mathbf{m}^{3} / \mathbf{s}\right)\end{array}$ & $\begin{array}{l}\text { Channel } \\
\text { condition }\end{array}$ \\
\hline Secondary drainage at Jl. Pemuda & 0.899 & 1.003 & - & Optimal \\
\hline Secondary drainage at Jl. Bhayangkara & 0.638 & 0.872 & - & Optimal \\
\hline Secondary drainage at J1. Kyai Jebat & 0.674 & 0.538 & 0,136 & Overflowed \\
\hline Secondary drainage in Merbotan & 0.438 & 0.349 & 0.089 & Overflowed \\
\hline Tertiary drainage at Jl. Pattimura & 0.589 & 0.091 & 0.498 & Overflowed \\
\hline $\begin{array}{l}\text { Secondary drainage at Jl. Kyai } \\
\text { Palembang }\end{array}$ & 0.225 & 0.463 & - & Optimal \\
\hline Tertiary drainage at Jl. Kyai Mugni & 0.211 & 0.055 & 0.156 & Overflowed \\
\hline Drainage at Jl. Kyai Singkil & 0.965 & 1.029 & - & Optimal \\
\hline Drainage in front of Pendopo & 0.128 & 0.349 & - & Optimal \\
\hline
\end{tabular}


Table 9. Inundation discharge calculation with rainfall repetition period (RRP) of 5 years

\begin{tabular}{llccc}
\hline \multicolumn{1}{c}{ Drainage channel } & $\begin{array}{c}\text { Q } \\
\left(\mathbf{m}^{3} \mathbf{3} \mathbf{s}\right)\end{array}$ & $\begin{array}{c}\text { QExisting } \\
\left(\mathbf{m}^{3} / \mathbf{s}\right)\end{array}$ & $\begin{array}{c}\text { Q } \\
\left(\mathbf{m}^{\mathbf{3}} / \mathbf{s}\right)\end{array}$ & $\begin{array}{c}\text { Channel } \\
\text { condition }\end{array}$ \\
\hline Secondary drainage atJl. Pemuda & 1.161 & 1.003 & 0.158 & Overflowed \\
Secondary drainage at J1. Bhayangkara & 0.808 & 0.872 & - & Optimal \\
Secondary drainage at J1. Kyai Jebat & 0.860 & 0.538 & 0.322 & Overflowed \\
Secondary drainage in Merbotan & 0.533 & 0.349 & 0.183 & Overflowed \\
Tertiary drainage at Jl. Pattimura & 0.740 & 0.091 & 0.649 & Overflowed \\
Secondary drainage at J1. Kyai & 0.277 & 0.463 & - & Optimal \\
Palembang & & 0.055 & 0.205 & Overflowed \\
Tertiary drainage at Jl. Kyai Mugni & 0.260 & 1.029 & 0.177 & Overflowed \\
Drainage Jl. Kyai Singkil & 1.207 & 0.349 & - & Optimal \\
Drainage in front of Pendopo & 0.155 & & & \\
\hline
\end{tabular}

Source : Researcher analysis, 2019

Table 10. Inundation discharge calculation with rainfall repetition period (RRP) of 10 years

\begin{tabular}{|c|c|c|c|c|}
\hline Drainage channel & $\begin{array}{c}\mathbf{Q}_{\text {plan }} \\
\left(\mathbf{m}^{3} / \mathbf{s}\right)\end{array}$ & $\begin{array}{l}Q_{\text {existing }} \\
\left(\mathbf{m}^{3} / \mathbf{s}\right)\end{array}$ & $\begin{array}{c}\text { QInundation } \\
\left(\mathrm{m}^{3} / \mathrm{s}\right)\end{array}$ & $\begin{array}{l}\text { Channel } \\
\text { condition }\end{array}$ \\
\hline Secondary drainage atJl. Pemuda & 1.369 & 1.003 & 0.37 & Overflowed \\
\hline Secondary drainage at Jl. Bhayangkara & 0.943 & 0.872 & 0.07 & Overflowed \\
\hline Secondary drainage at J1. Kyai Jebat & 1.008 & 0.538 & 0.47 & Overflowed \\
\hline Secondary drainage in Merbotan & 0.610 & 0.349 & 0.26 & Overflowed \\
\hline Tertiary drainage at Jl. Pattimura & 0.861 & 0.091 & 0.77 & Overflowed \\
\hline $\begin{array}{l}\text { Secondary drainage at Jl. Kyai } \\
\text { Palembang }\end{array}$ & 0.318 & 0.463 & - & Optimal \\
\hline Tertiary drainage at Jl. Kyai Mugni & 0.299 & 0.055 & 0.24 & Overflowed \\
\hline Drainage Jl. Kyai Singkil & 1.400 & 1.029 & 0.37 & Overflowed \\
\hline Drainage in front of Pendopo & 0.178 & 0.349 & - & Optimal \\
\hline
\end{tabular}

Source : Researcher analysis, 2019

\subsection{The analysis of the rainfall infiltration well ecodrainage model in handling the inundation in the city center of Demak}

The classification of the rainfall infiltration well, suitable to the application based on SNI 03-2453-2002 was the well type II with a red brick wall and with a gap between the pairs. The well could be applied to all types of soil. This type of well was planned to be a square with a side area of $1.00 \times 1.00 \mathrm{~m}$ with a depth of $2.00 \mathrm{~m}$. Design of the well could be seen more clearly in Figure 3. below.

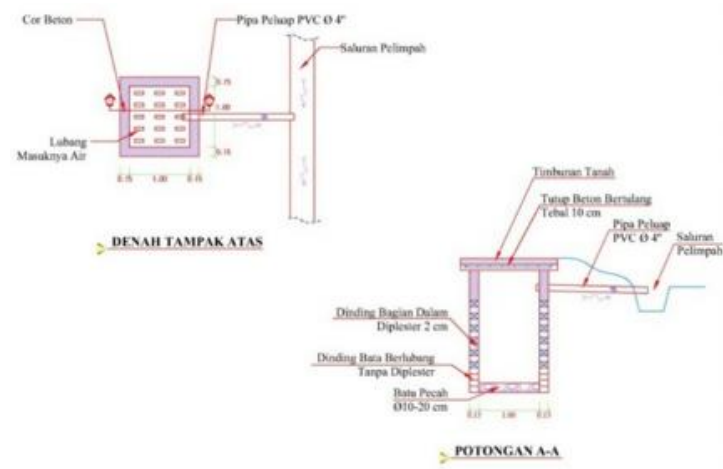

Fig. 3. The rainfall infiltration well Design 
The application of the rainfall infiltration well was an alternative solution in an effort to handle inundation in the city center of Demak during the rainy season. This well would only accommodate rain water which was then channeled to the nearest drain or drainage channel. This well discharge can be calculated with the following equation:

$$
Q_{U}=\frac{2 \pi}{u\left(\frac{L}{2 R}+\sqrt{1+\left(\frac{L}{2 R}\right)^{2}}\right)}
$$

Explanation:

Qo : Infiltrated discharge ( $\left.\mathrm{m}^{3} / \mathrm{second}\right)$

$\mathrm{L}$ : Height of infiltration well which seep into ground (m)

$\mathrm{H}$ : Water level in the well (m)

$\mathrm{K}$ : Soil permeability coefficient ( $\mathrm{m} / \mathrm{second})$

$\mathrm{R}$ : Radius of the well (m)

$$
H=\frac{Q}{f}\left\{1-e \quad\left(\frac{-f}{b}\right)\right\}
$$

Explanation:

$\mathrm{H}$ : Depth of well (m)

F : Geometric factors (m)

Q : Incoming water discharge $\left(\mathrm{m}^{3} /\right.$ second)

$\mathrm{T}$ : Drainage time (detik)

$\mathrm{K}$ : Soil permeability coefficient ( $\mathrm{m} / \mathrm{second})$

$\mathrm{R}$ : Radius of well (m)

The calculation results can be seen in the following table

Table 11. Calculation of the rainfall infiltration well (RIW) quantity with the rainfall repetition period (RRP) of 2 years

\begin{tabular}{clcccc}
\hline No. & \multicolumn{1}{c}{ Location of RIW } & $\begin{array}{c}\text { Qinundation } \\
\left(\mathbf{m}^{\mathbf{3}} / \mathbf{s}\right)\end{array}$ & $\begin{array}{c}\text { QRIW } \\
\left(\mathbf{m}^{\mathbf{3}} / \mathbf{s}\right)\end{array}$ & $\begin{array}{c}\text { Number of RIW needed } \\
(\mathbf{u n i t})\end{array}$ & $\begin{array}{c}\text { Number of constructed } \\
\text { RIW (Unit) }\end{array}$ \\
\hline 1. & Jl. Pemuda & - & - & - & - \\
2. & Jl. Bhayangkara & - & - & - & - \\
3. & Jl. Kyai Jebat & 0.136 & 0.0429 & 3 & 3 \\
4. & Merbotan & 0.089 & 0.0429 & 2 & 2 \\
5. & Jl. Pattimura & 0.498 & 0.0429 & 12 & 10 \\
6. & Jl. Kyai Palembang & - & - & - & - \\
7. & Jl. Kyai Mugni & 0.156 & 0.0429 & 4 & - \\
8. & Jl. Kyai Singkil & - & - & - & - \\
9. & Depan Pendopo & - & - & - & 19 \\
\hline
\end{tabular}

Source : Researcher analysis, 2019 
Table 12. Calculation of the rainfall infiltration well (RIW) quantity with the rainfall repetition period (RRP) of 5 years

\begin{tabular}{clcccc}
\hline No. & \multicolumn{1}{c}{ Location of RIW } & $\begin{array}{c}\text { Qinundation } \\
\left(\mathbf{m}^{3} / \mathbf{s}\right)\end{array}$ & $\mathbf{Q}_{\mathbf{R I W}}\left(\mathbf{m}^{\mathbf{3}} \mathbf{/ s}\right)$ & $\begin{array}{c}\text { Number of RIW } \\
\text { needed (unit) }\end{array}$ & $\begin{array}{c}\text { Number of } \\
\text { constructed RIW } \\
\text { (Unit) }\end{array}$ \\
\hline 1. & J1. Pemuda & 0.158 & 0.0429 & 4 & 4 \\
2. & J1. Bhayangkara & - & - & - & - \\
3. & J1. Kyai Jebat & 0.322 & 0.0429 & 8 & 8 \\
4. & Merbotan & 0.183 & 0.0429 & 4 & 4 \\
5. & J1. Pattimura & 0.649 & 0.0429 & 15 & 10 \\
6. & J1. Kyai Palembang & - & - & - & - \\
7. & J1. Kyai Mugni & 0.205 & 0.0429 & 5 & 5 \\
8. & J1. Kyai Singkil & 0.177 & 0.0429 & 4 & 4 \\
9. & Depan Pendopo & - & - & - & - \\
& & & & 40 & 35 \\
\hline
\end{tabular}

Source : Researcher analysis, 2019

Table 13. Calculation of the rainfall infiltration well (RIW) quantity with the rainfall repetition period (RRP) of 10 years

\begin{tabular}{|c|c|c|c|c|c|}
\hline No. & Location of RIW & $\begin{array}{c}Q_{\text {inundation }} \\
\left(\mathbf{m}^{3} / \mathbf{s}\right)\end{array}$ & $\mathbf{Q}_{\mathrm{RIW}}\left(\mathbf{m}^{3} / \mathbf{s}\right)$ & $\begin{array}{c}\text { Number of RIW } \\
\text { needed (unit) }\end{array}$ & $\begin{array}{c}\text { Number of } \\
\text { constructed RIW } \\
\text { (Unit) }\end{array}$ \\
\hline 1. & Jl. Pemuda & 0.37 & 0.0429 & 9 & 9 \\
\hline 2. & Jl. Bhayangkara & 0.07 & - & 2 & 2 \\
\hline 3. & J1. Kyai Jebat & 0.47 & 0.0429 & 11 & 8 \\
\hline 4. & Merbotan & 0.26 & 0.0429 & 6 & 4 \\
\hline 5. & Jl. Pattimura & 0.77 & 0.0429 & 18 & 10 \\
\hline 6. & Jl. Kyai Palembang & - & - & - & - \\
\hline 7. & Jl. Kyai Mugni & 0.24 & 0.0429 & 6 & 5 \\
\hline 8. & Jl. Kyai Singkil & 0.37 & 0.0429 & 9 & 9 \\
\hline \multirow[t]{2}{*}{9.} & Depan Pendopo & - & - & - & - \\
\hline & & & & 61 & 47 \\
\hline
\end{tabular}

Source : Researcher analysis, 2019

\section{Conclusion}

Based on the analysis and discussion in the previous chapter, it can be concluded that:

1. The drainage system in Demak city center was conventional drainage that still did not function optimally and caused inundation during the rainy season. Inundation in the area occurred because most of the drainage experienced siltation due to sedimentation, clogged with garbage, overgrown with wild plants and damage to physical buildings;

2. Existing discharge of drainage in the city center of Demak was $4.750 \mathrm{~m}^{3} / \mathrm{s}$.

3. Plan discharge of drainage in city center of Demak was a combination of dirty water and rainwater discharge. The plan discharge based on rainfall repetition period is as follows

a. Based on the rainfall repetition period (RRP) of 2 years was $4.766 \mathrm{~m}^{3} / \mathrm{s}$;

b. Based on the rainfall repetition period (RRP) of 5 years was $6.001 \mathrm{~m}^{3} / \mathrm{s}$; 
c. Based on the rainfall repetition period (RRP) of 10 years was $6.988 \mathrm{~m}^{3} / \mathrm{s}$;

4. Rainfall infiltration well was an alternative ecodrainage that was expected to overcome the inundation in the city center of Demak. The quantity of the well required based on the rainfall repetition period in the city center of Demak is as follows:

a. Based on the rainfall repetition period of 2 years as many as 21 units of wells were needed to accommodate rainwater runoff discharges of $0.878 \mathrm{~m}^{3} / \mathrm{s}$. However, due to land limits in the research area, only could 20 wells be applied, and as a result, the inundation reduced was $0.811 \mathrm{~m}^{3} / \mathrm{s}$ or equal to $90.48 \%$ of the total inundation, occurred and so it still left an inundation discharge of $0.085 \mathrm{~m}^{3} / \mathrm{s}$ or as much as $9.52 \%$.

b. Based on the the rainfall repetition period of 5-year as many as 40 units of wells were needed to accommodate rainwater runoff discharges of $1.70 \mathrm{~m}^{3} / \mathrm{s}$. However, only could 33 units be realized, as the result, the inundation reduced was $1.494 \mathrm{~m}^{3} / \mathrm{s}$ or $87.50 \%$ of the total amount of the inundation occurred and so in the city center of Demak within the rainfall repetition period of 5 years, this condition would still leave inundation discharge of $0.213 \mathrm{~m}^{3} / \mathrm{s}$ or as much as $12.50 \%$.

c. Based on the the rainfall repetition period of 10-years as many as 61 units of wells were needed to accommodate rainwater runoff discharges of $2.554 \mathrm{~m}^{3} / \mathrm{s}$. However, only could 47 units be realized, as the result, the inundation reduced was $2.01 \mathrm{~m}^{3} / \mathrm{s}$ or $77.05 \%$ of the total amount of the inundation occurred and so in the city center of Demak within the rainfall repetition period of 10 years, this condition would still leave inundation discharge of $0.598 \mathrm{~m}^{3} / \mathrm{s}$ or as much as $23.95 \%$.

\section{References}

[1] Ardiyansyah, R. 2015. Analisa Hidrologi dan Hidrolika Saluran Drainase Box Culvert Di Jalan Antasari Bandar Lampung Menggunakan Program Hec-Ras. JRSDD. 3(1): 1-12

[2] Dinas Pekerjaan Umum dan Penataan Ruang Kabupaten Demak. 2017. Laporan Akhir Penyusunan Database Drainase Kota Demak

[3] Habibi, Munzirwan. 2017. Strategi Penerapan Eko-Drainase Di Kawasan Gampoeng Keuramat Banda Aceh. Jurnal Teknik Sipil Universitas Syiah Kuala. 6(3): 1-5

[4] Harto Br, S. 1995. Analisis Hidrologi. Jakarta: Penerbit Gramedia

[5] Nurhapni. 2008. Kajian Pembangunan Sistem Drainase Berwawasan Lingkungan Di Kawasan Perumahan. Jurnal Perencanaan Wilayah dan Kota. 11(1): 1-12

[6] Pemerintah Kabupaten Demak. Peraturan Daerah Kabupaten Demak Nomor 6 Tahun 2011 tentang Rencana Tata Ruang Wilayah (RTRW) Kabupaten Demak Tahun 2011-2031

[7] Pitaloka, M. G. 2017. "Perencanaan Sistem Drainase Kebon Agung Kota Surabaya, Jawa Timur". Jurnal Teknik ITS. 6(1). C1-C6

[8] SNI 03-2453-2002. 2002. Tata Cara Perencanaan Teknik Sumur Resapan Air hujan Untuk Lahan Pekarangan. Standarisasi Badan Litbang Kimpraswil. Jakarta

[9] Sunjoto. 1987. "Sistem Drainase Air Hujan yang Berwawasan Lingkungan”, Makalah Seminar Pengkajian Sitem Hidrologi dan Hidrolika, PAU Ilmu Teknik Universitas Gajah Mada

[10] Suripin. 2004. Sistem Drainase Perkotaan yang Berkelanjutan. Jojakarta: Andi 